\title{
THE INFLUENCE OF DIFFERENT PECKING DEPTH ON AMOUNT OF APICALLY EXTRUDED DEBRIS DURING ROOT CANAL PREPARATION
}

\section{KÖK KANAL PREPARASYONU SIRASINDA FARKLI GAGALAMA DERİNLİĞİNİN APİKAL DEBRİS MİKTARINA ETKİSİ}

\author{
Dr. Öğr. Üyesi Fatih ÇAKICI \\ Dr. Öğr. Üyesi Elif Bahar ÇAKICI
}

\author{
Arş. Gör. Busra UYSAL \\ Arş. Gör. Adem GÜNAYDIN
}

\author{
Makale Kodu/Article code: 4394 \\ Makale Gönderilme tarihi: 21.05 .2020 \\ Kabul Tarihi: 07.10.2020 \\ DOI : $10.17567 /$ ataunidfd. 806853
}

Fatih CakıcI: ORCID ID: 0000-0002-8147-2661

Büșra Uysal : ORCID ID: 0000-0003-3558-9620

Elif Bahar Cakıcı : ORCID ID: 0000-0002-5769-0239

Adem Günaydın : ORCID ID: 0000-0002-3300-3342

\section{ABSTRACT}

Aim: The aim of this study was to compare apically extruded debris caused by different pecking depth of Reciproc and HyFlex EDM systems.

Materials and Methods: Seventy-two human mandibular premolar teeth were randomly divided into 4 experimental groups $(n=18)$ based on the file type and pecking depths. In Group 1, a HyFlex EDM (Coltene-Whaledent, Allstetten, Switzerland) with $2 \mathrm{~mm}$ distance was used, in Group 2, HyFlex EDM with $4 \mathrm{~mm}$ distance was used. In Group 3, Reciproc (VDW, Munich, Germany) with $2 \mathrm{~mm}$ distance was used, and in Group 4, Reciproc with $4 \mathrm{~mm}$ distance was used. The apically extruded debris was collected in pre-weighed Eppendorf tubes. Three sequential weight measurements were recorded for each Eppendorf tubes, and the average values were noted. Debris amount was calculated by subtracting the weight of the empty tubes from the weight of the tubes containing the debris. The data were analyzed using one-way analysis of variance (ANOVA) and Tukey's post hoc tests.

Results: There was statistically significant difference between Group 4 (Reciproc with $4 \mathrm{~mm}$ distance) and all the other groups $(p<0.05)$, while no statistically significant was found among the other groups $(p>0.05)$. The preparation time was the statistically significantly different between groups $(p=0,008)$ and preparation time was longer in Group 1 than in Group 2 $(\mathrm{p}=0,012)$ and Group $4(0,017)$

Conclusions: Within the limitations of the present study, all groups led to a measurable apical extrusion of debris and reciprocal motion with increasing the pecking depth caused the most debris extrusion.

Keywords: Apical debris extrusion, pecking depth, reciprocating, root canal treatment, rotating, single-file system.

öz

Amaç: Reciproc ve HyFlex EDM sistemlerinin farklı gagalama derinliklerinin neden olduğu apikale itilmiş debris miktarını karşılaştırmaktır.

Gereç ve yöntem: Yetmiş iki insan alt çene küçük azı dişi, kullanılan eğe ve gagalama derinliklerine göre rastgele 4 deney grubuna ayrıldı $(n=18)$. Grup 1'de $2 \mathrm{~mm}$ mesafede bir HyFlex EDM (Coltene-Whaledent, Allstetten, İsviçre), Grup 2'de $4 \mathrm{~mm}$ mesafede HyFlex EDM kullanılmıştır. Grup 3'te $2 \mathrm{~mm}$ mesafe ile Reciproc (VDW, Münih, Almanya), Grup 4 'te 4 mm mesafe ile Reciproc kullanıldı. Apikalden dışarı çıkmış debris, önceden tartılmış Eppendorf tüplerinde toplandı. Daha sonra her Eppendorf tüpü için üç ardışık ağılık ölçümü okundu ve ortalama değer kaydedildi. Debris miktarı, boş tüplerin ağırlığının, debris içeren tüplerin ağırlığından çıkarılmasıyla hesaplanmıştır. Veriler tek yönlü varyans analizi (ANOVA) ve Tukey'in post hoc testleri kullanılarak analiz edildi.

Bulgular: Grup 4 (4 mm mesafe ile Reciproc) ve diğer tüm gruplar $(p<0.05)$ arasında istatistiksel olarak anlamlı fark bulunurken, diğer gruplar arasında istatistiksel olarak anlamlı fark bulunmadı ( $p>0.05)$. Preparasyon süresi gruplar arasında istatistiksel olarak anlamlı derecede farklıydı $(p=0,008)$ ve preparasyon süresi Grup 1'de Grup 2'ye $(p=0,012)$ ve Grup 4'e $(0,017)$ göre daha uzundu.

Sonuçlar: Bu çalıșmanın sınırlamaları dâhilinde, tüm gruplarda ölçülebilir bir apikal debris çıkışı görüldü ve reciprocal hareket ile artan gagalama derinliği en fazla debris çıkışına sebep oldu.

Keywords: Apikal enkaz ekstrüzyonu, gagalama derinliği, ileri geri hareket eden, kanal tedavisi, döndürme, tek eğe sistemi.

\footnotetext{
* Ordu Üniversitesi, Dis Hekimliăi Fakültesi, Endodonti Anabilim Dalı, Ordu.
}

\footnotetext{
Kaynakça Bilgisi: Çakııı F, Uysal B, Çakıı EB, Günaydın A. Kök kanal preparasyonu sırasında farklı gagalama derinliğinin apikal debris miktarına etkisi Atatürk Üniv Diş Hek Fak Derg 2021; 31: 34-8.

Citation Information: Cakici $F$, Uysal B, Cakici EB, Gunaydin A. The influence of different pecking depth on amount of apically extruded debris during root canal preparation. J Dent Fac Atatürk Uni 2021; 31: 34-8.
} 


\section{INTRODUCTION}

The shaping procedure of root canals has significant effect on success of endodontic treatment. ${ }^{1-3}$ icroorganisms, dentin chips, pulp tissue or irrigation solution may be extruded into the periapical tissues during the biomechanical preparation. ${ }^{4}$.The apical extrusion phenomenon may cause unwanted postoperative complications such as pain, periapical inflammation, delay of periapical healing, and edema. ${ }^{5-7}$ The researches of scientists have demonstrated that the amount of apically extruded debris might change with the type of instrument and motion. ${ }^{8-10}$ Researchers are encouraged to discover new single file systems supporting better treatment in a shorter time. Recently, HyFlex EDM (Coltene-Whaledent, Allstetten, Switzerland) System has been introduced. It is a continuous rotary single file system, consisting of 6 instruments manufactured using controlled memory (CM) alloy and EDM (Electrical Discharge Machining) technology. Furthermore, Reciproc (VDW, Munich, Germany) system has been introduced as a single file system, consisting of 3 instruments and using reciprocal motion. ${ }^{11}$ Unfortunately, these systems also require using of the initial files before the instruments with wide diameter, and pulling back the instrument when it encounters resistance. Investigators want to explore new instrument techniques to overcome these difficulties.

To our best knowledge, research data about the effect of different pecking depth on apical extruded debris were not yet available at the time of this study. Therefore, in this study we aimed to compare apically extruded debris caused by different pecking depth of Reciproc and HyFlex EDM instruments. The null hypothesis was that there was no difference between Reciproc and HyFlex EDM systems in terms of the amount of apically extruded debris caused by different pecking depth.

\section{MATERIALS AND METHODS}

This experimental study was approved by the Ethics Committee of Clinical Research of Ordu university (2019-29).Mandibular premolar human teeth were used in this study. The deposits such as calculus and soft tissue on the root surface were cleaned. The teeth were assessed both from both buccal and lingual aspects on radiographs. Exclusion criteria were teeth with an apical diameter $>15$, calcifications, prosthetic crowns, root resorption, formerly endodontic treatment, dental posts, unnatural root canal morphology, and with a root curvature $<10^{0}$ according to Schneider. ${ }^{12}$ According to above criteria, 72 teeth were selected from a collection of 170 mandibular premolars with a closed apex. The working length was adjusted as $1 \mathrm{~mm}$ shorter than the distance where a \#10 K-file (e (VDW $\mathrm{GmbH}$, Munich, Germany) was advanced to the level of light visibility at the apical foramen. Crowns of teeth were flattened with a high-speed diamond bur to acquire a 16-mm tooth length then standard access cavities were prepared under water cooling in all teeth.

The teeth were randomly divided into 4 experimental groups $(n=18)$ based on the file and pecking depths. The teeth were randomized to the groups using a website (http://www.random.org).

Root Canal Instrumentation

Group 1 (HyFlex EDM with 2mm Distance):

The root canals were prepared at $500 \mathrm{rpm}$, and $2.5 \mathrm{Ncm}$ torque values using HyFlex EDM instrument (50/.03). Pecking motion was modified as following; the instrument was put into the root canal and pushed forward $2 \mathrm{~mm}$ to apical after encountered resistance. This movement was repeated until reached the working length.

Group 2 (HyFlex EDM with 4mm Distance):

The root canals were prepared at $500 \mathrm{rpm}$ and $3.5 \mathrm{Ncm}$ torque values using HyFlex EDM instrument (50/.03). Pecking motion was modified as following; the instrument was put into the root canal and pushed forward $4 \mathrm{~mm}$ to apical after encountered resistance. This movement was repeated until reached the working length.

\section{Group 3 (Reciproc with 2mm Distance):}

The root canals were prepared with "Reciproc ALL" program using the Reciproc R50 (50/.05) instrument. The pecking motion was modified as following; the instrument was put into the root canal and pushed forward $2 \mathrm{~mm}$ to apical after encountered resistance. This movement was repeated until reached the working length.

\section{Group 4 (Reciproc with 4mm Distance):}

The root canals were prepared at "Reciproc ALL" program using the Reciproc R50 (50/.05) instrument. Pecking motion was modified as following; the instrument was put into the root canal and pushed forward $4 \mathrm{~mm}$ to apical after encountered resistance. This movement was repeated until reached the working length. 


\section{Setup Experimental}

A hole on each rubber stopper was prepared and the tooth was fixed the hole. 25-G needle was used to equalize the inside and outside air pressure of Eppendorf tube. Then, each rubber stopper with the needle and the tooth was fixed to an Eppendorf tube and around of each needle and root was sealed with cyanoacrylate to stop leakage of the distilled water from the hole. All tubes were then placed into vials covered with a rubber dam to inhibit observation the amount of apical extrusion by the operator during preparation. In addition, pecking depth on the produced apparatus, which we produced, was measured using a ruler. (Fig 1)

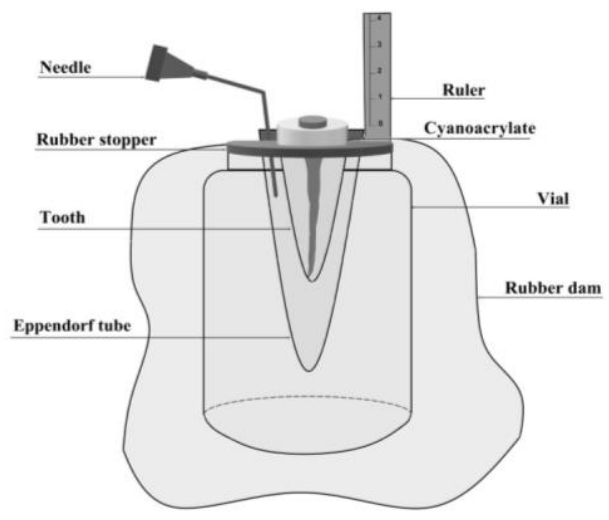

Fig. 1.schematic illustration of the modified apparatus.

For all groups; after each three times of pecking motion, the instrument was drawn back and wiped up with a wet gauze patch. The root canals were irrigated with a 29-G side port irrigation needle (Ultradent, South Jordan, UT, USA). Totally $25 \mathrm{ml}$ distilled water was exhaust during shaping procedures. Each instrument was used for preparation of only three teeth. In addition, time of the preparation process was recorded using a digital chronometer excluding canal irrigations and file replacements.

\section{Debris collection}

After preparation was completed, the rubber stopper, needle, and root were removed. The debris on the apical part of the specimen was collected through irrigation with $1 \mathrm{ml}$ irrigation solution in the Eppendorf. To evaporate the distilled water, each Eppendorf tubes were conserved in an incubator at $70^{\circ} \mathrm{C}$ for 120 hours before weighing the dry extruded debris. ${ }^{13}$ The Eppendorf tubes were weighed at precision of $10^{-5}$ by a microbalance (AUW-220D;
Shimadzu, Tokyo, Japan). Three successive measurements were recorded for each Eppendorf tubes, and the mean values were registered. The debris amount was found by subtracting the weight of the empty Eppendorf tubes from the Eppendorf tubes containing the debris.

\section{Statistical analysis}

The descriptive analyses for procedure time and amount of apical extruded debris were calculated. The normality of the variation of the data was confirmed by the shapiro-wilk test. The results were analyzed by one-way analysis of variance (ANOVA). For multiple comparisons was used Tukey's post hoc test. A significance level of \%95 was used for all statistical tests. IBM Corp. Released 2015 IBM SPSS Statistics for Windows (Version 23.0. Armonk, NY: IBM Corp. USA) was used for Statistical tests.

\section{RESULTS}

The results indicated that all groups caused measurable debris extrusion. Table 1 demonstrates the mean and standard deviation values of each group. There was statistically difference among the groups $(p<0.05)$. The highest amount of extruded debris was found in group 4, while there was not statistically difference among the other groups ( $p>0.05)$. In Group 4, one file was fractured.

There was statistically difference among the groups $(p=0,008)$ according to instrumentation time. It was longer in group 1 than group $2(p=0,012)$ and group $4(p=0,017)$ (Table 2$)$.

Table 1.Mean, standard deviations (SD) of the amount of apically extruded debris of each group (in grams)

\begin{tabular}{|c|c|}
\hline Group & Mean \pm SD \\
\hline Group 1 $(n=18)$ & $0,00047^{\mathrm{a}} \pm 0,00028$ \\
\hline Group 2 $(n=18)$ & $0,00060^{\mathrm{a}} \pm 0,00032$ \\
\hline Group 3 $(\mathrm{n}=18)$ & $0,00041^{\mathrm{a}} \pm 0,00026$ \\
\hline Group 4 $(\mathrm{n}=18)$ & $0,00100^{\mathrm{b}} \pm 0,00036$ \\
\hline
\end{tabular}

Values with the same letters were not significantly different at $\mathrm{P}=0.05$.

Table 2.Mean, standard deviations (SD) of the preparation time (seconds)

\begin{tabular}{|c|c|}
\hline Group & Mean \pm SD \\
\hline Group 1 $(n=18)$ & $30,8^{\mathrm{b}} \pm 5,2$ \\
\hline Group 2 $(\mathrm{n}=18)$ & $24,1^{\mathrm{a}} \pm 7,5$ \\
\hline Group 3 $(\mathrm{n}=18)$ & $26,2^{\mathrm{ab}} \pm 7,5$ \\
\hline Group 4 $(\mathrm{n}=18)$ & $24,3^{\mathrm{a}} \pm 5,2$ \\
\hline
\end{tabular}

Values with the same letters were not significantly different at $\mathrm{P}=0.05$. 


\section{DISCUSSION}

This study we aimed to compare apically extruded debris caused by different pecking depth of Reciproc and HyFlex EDM instruments. The null hypothesis was that there was no difference between Reciproc and HyFlex EDM systems in terms of the amount of apically extruded debris caused by different pecking depth. According to results of the present study, there was statistically difference among groups. Thus, the null hypothesis was rejected.

Apical extruded debris leads to postoperative complications such as pain, inflammation and delayed healing of periapical area. ${ }^{14}$ Recently, the researchers and clinicians have conducted many studies about it. When they compare multi-file and single-file rotary instrumentation, ${ }^{15}$,there are two assumptions about systems. The first of these argued that the single-file systems cause significantly higher amount of extruded debris compared with the multi-file continuous rotary instrument systems..$^{5-17}$ The second one contrarily argued that multi-file rotary systems cause significantly higher amount of extruded debris compared with single file systems. ${ }^{17,18}$ The present study was conducted with single file systems.

Another important factor on extruded debris is instrument kinetics. Researchers reported that continuous rotary instrument system caused less extruded apical debris. ${ }^{15,16}$ However, some researchers opposed this assumption and claimed that rotary systems cause higher amount of apically extruded debris than Reciprocal systems. ${ }^{19,20}$ Moreover, Kocak et al. ${ }^{13}$ reported that there was not statistically significant difference between reciprocal instrumentation and continuous rotary instrumentation in terms of debris extrusion. Current study indicated that there was not significant difference between two systems. This result was supported by the study of Kocak et al. ${ }^{13}$ The differences between the studies may be due to the properties of used teeth, types of used instruments, differences between the operators.

The apical debris was collected by the generally accepted method of Myers \& Montgomery. ${ }^{21}$ The current experimental model has disadvantage related to the apical part of the root suspends in air without any physical barrier, and clinical conditions are not mimicked. ${ }^{21}$ Another experimental set up has been recommended to simulate periapical tissues with floral foam to better represent clinical conditions such as physical back pressure. ${ }^{22}$ However, the researchers have claimed that the foam may absorb some amount of debris and irrigation solution, when used as a barrier. ${ }^{16,22}$. In present study we used modified method of Myers \& Montgomery. ${ }^{21}$ In addition, in this study we used distilled water instead of sodium hypochlorite, because sodium hypochlorite inclines to crystallize. ${ }^{9}$

Manufactured companies have suggested that the instruments should gently be advanced into the root canal and pull back when it encounters resistance. Otherwise, fracture or deformation of instrument may be occurred. The requirement of using initial files before the instruments with wide diameter for gently preparation and pulling back the instrument when it encounters resistance are cause loss of time. The clinicians want to use long pecking depth to complete the preparation in the shortest time. In the best knowledge, there is not study on pecking depth and torque value thus we cannot discuss about it.

\section{CONCLUSION}

Within the limitations of this study; increasing pecking depth and torque value reduced working time without changing apically extruded debris. However, stable torque value with increasing pecking depth causes increasing amount of apically extruded debris and fracture of instrument.

\section{Acknowledgements}

The authors declare that there were no other contributors involved in this work

Conflicts of interest statement

The authors declare no conflict of interest.

\section{REFERENCES}

1. Van Pham K, Vo CQ. A new method for assessment of nickel-titanium endodontic instrument surface roughness using field emission scanning electronic microscope. BMC Oral Health 2020;20:240.

2. Tufenkci P, Yilmaz K, Adiguzel M. Effects of the endodontic access cavity on apical debris extrusion during root canal preparation using different single-file systems. Restor Dent Endod 2020;45:33.

3. Conceicao I, Ferreira I, Braga AC, Pina-Vaz I. Simulated root canals preparation time, comparing ProTaper Next and WaveOne Gold systems, performed by an undergraduate student. J Clin Exp Dent 2020;12:730-5. 
4. Kirchhoff $A L$, Fariniuk LF, Mello I. Apical extrusion of debris in flat-oval root canals after using different instrumentation systems. J Endod 2015; 41: 237-41

5. Yammine SD, Jabbour EA. Apically extruded debris following programmed over instrumentation of curved canals with three nickel titanium rotary Instruments. Eur J Dent 2020. Article in press

6. Keskin C, Sivas Yilmaz O, Inan U. Apically extruded debris produced during glide path preparation using R-Pilot, WaveOne Gold Glider and ProGlider in curved root canals. Aust Endod J 2020. Article in press

7. Ozlek E, Neelakantan P, Khan K, Cheung GSP, Rossi-Fedele G. Debris extrusion during root canal preparation with nickel-titanium instruments using liquid and gel formulations of sodium hypochlorite in vitro. Aust Endod J 2020. Article in press

8. Tanalp J, Güngör T. Apical extrusion of debris: a literature review of an inherent occurrence during root canal treatment. Int Endod J 2014; 47: 21121

9. Ahmad MZ, Sadaf D, MacBain MM, Mohamed AN. Apical extrusion of debris with different rotary and reciprocating single-file endodontic instrumentation systems: a systematic review and meta-analysis protocol. BMJ Open 2020;10:038502.10.

10. Üstün $Y$, Çanakçi BC, Dinçer AN, Er O, Düzgün S. Evaluation of apically extruded debris associated with several $\mathrm{Ni}-\mathrm{Ti}$ systems. Int Endod J 2015; 48: 701-4

11. Adigüzel $M$, Tüfenkçi $P$. Comparison of the cyclic fatigue resistance of waveone, reciproc and twisted file adaptive files in canals with a double curvature (s-shaped). J Dent Fac Atatürk Uni 2018; 28: 199-203

12. Schneider SW. A comparison of canal preparations in straight and curved root canals. Oral Surg Oral Med Oral Pathol 1971; 32: 271-5

13. Koçak S, Koçak MM, Sağlam BC, Türker SA, Sağsen $B$, Er Ö. Apical extrusion of debris using selfadjusting file, reciprocating single-file, and 2 rotary instrumentation systems. . J Endod 2013; 39: 1278-80

14. Saha SG, Gupta RK, Bhardwaj A, Misuriya A, Saha MK, Nirwan AS. Comparison of the incidence of postoperative pain after using a continuous rotary system, a reciprocating system, and a SelfAdjusting File system in single-visit endodontics: A prospective randomized clinical trial. J Conserv Dent 2018;21:333-8.

15. Bürklein S, Schäfer E. Apically extruded debris with reciprocating single-file and full-sequence rotary instrumentation systems. J Endod Odontic 2012; 38: $850-2$

16. Bürklein S, Benten S, Schäfer E. Quantitative evaluation of apically extruded debris with different single-file systems: Reciproc, F360 and OneShape versus Mtwo. Int Endod J 2014; 47: 405-9

17. Robinson JP, Lumley PJ, Cooper PR, Grover LM, Walmsley AD. Reciprocating root canal technique induces greater debris accumulation than a continuous rotary technique as assessed by 3dimensional micro-computed tomography. . J Endod 2013; 39: 1067-70

18. Tinoco JM, De-Deus G, Tinoco EMB, Saavedra F, Fidel RAS, Sassone LM. Apical extrusion of bacteria when using reciprocating single-file and rotary multifile instrumentation systems. Int Endod J 2014; 47: 560-6

19. De-Deus G, Neves A, Silva EJ, Mendonça TA, Lourenço $C$, Calixto $C$, et al. Apically extruded dentin debris by reciprocating single-file and multifile rotary system. Clin Oral Investig 2015; 19: 357-61

20. Ozsu D, Karatas E, Arslan H, Topcu MC. Quantitative evaluation of apically extruded debris during root canal instrumentation with ProTaper Universal, ProTaper Next, WaveOne, and selfadjusting file systems. Eur J Dent 2014; 8: 504-8

21. Myers GL, Montgomery S. A comparison of weights of debris extruded apically by conventional filing and canal master techniques. . J Endod 1991; 17: 275-9

22. Altundasar E, Nagas E, Uyanik O, Serper A. Debris and irrigant extrusion potential of 2 rotary systems and irrigation needles. . Oral Surg Oral Med Oral Pathol Oral Radiol Endod 2011; 112: e31-5

\author{
Sorumlu Yazarın Yazışma Adresi \\ Fatih Cakici, DDS, PhD \\ Endodontics, Dentistry Faculty \\ Ordu University \\ Ordu. 52000 \\ Tel: +905539791598 \\ E-mail: dt fatihcakici@hotmail.com
}

